John Cameron, Abena Eyeson*

\title{
Connecting Developments in Corporate Human Management Thinking to the Capability Approach as Used in International Development Research ${ }^{* *}$
}

This paper offers Amartya Sen's capability approach as a framework for understanding and evaluating Human Resource Development activities in larger organizations, specifically transnational corporations (TNCs). There is a growing literature on international human resource management targeted at people studying management in large organizations which has encouraged an element of cultural sensitivity in HR practices. This paper is concerned with demonstrating how the capability approach can help link the world of work to wider socio-economic and citizenship development. Human exploitation (more negative) and raising returns to human capital (more positive) are compared to the capability approach as models for understanding the impact of human resource management activities. For the Capability Approach, it is important to take into account the potential impact of HRD on people working for a TNC and on their wider well-being outside the TNC. A case study of TNCs in Ghana is used to explore how the capability approach can be applied in practice. The paper concludes with some reflections on how the approach may help provide a conceptual framework for the global discourse on TNCs as potential developmental agents.

Key words: human resource management, capability approach, decent work, corporate social responsibility, human capital, human exploitation (JEL: J24, J83, O15, Z10)

\footnotetext{
* Dr John Cameron and Dr Abena Eyeson, both Institute of Social Studies, Den Haag, The Netherlands. E-mail: cameron@iss.nl.

** Article received: April 3, 2011

Revised version accepted after double blind review: March 23, 2012.

management revue, 23(2), 173-190

ISSN (print) 0935-9915, ISSN (internet) 1861-9908

DOI 10.1688/1861-9908_mrev_2012_02_Cameron

(C) Rainer Hampp Verlag, www.Hampp-Verlag.de
} 


\section{Introduction}

This paper offers the capability approach as a framework for understanding and evaluating Human Resource Development activities in larger organisations operating internationally (hereafter transnational corporations or TNCs). The capability approach originated in the 1980s, in the writings of Amartya Sen, a Nobel Prize for Economics laureate. This work built on a seminal book on the causes of famine which highlighted the role of distributional processes in hunger related deaths (Sen, 1981). A central concept in Sen's book was 'entitlements'.

Every person has a set of entitlements (in this paper, offers of HRD resources from an employer constitute such entitlements whether or not the employee takes up the offer). An increase in entitlements can involve improved access to markets (including the labour market), public resources (including local, national and international education systems), and civil society institutions (including enhanced participation in valued cultural activities).

Deaths in a famine not only reflect a critical entitlements deficit, but are also extreme cases of losses of both capability and functionings. Where capability is the potential for undertaking a range of beings and doings, and functionings is the specific set of observable beings and doings that a person actually undertakes in some defined time period (e.g. a year, a working career, or a lifetime). A particular economic activity can be seen as a functioning alongside many other activities that give meaning to personhood. As a functioning, paid employment can be both an end providing resources for consumption and investment and a means to full personhood giving dignity, selfrespect, and respect in the eyes of others characterised by Amartya Sen's drawing on Adam Smith as 'the ability to appear in public without shame'.

Moving between entitlements, capability and functionings involves 'conversion' elements that provide systemic lubrication largely beyond individual influence. Conversion factors introduce a vital social dimension to what otherwise could give the capability approach an over-individualist focus. For instance, Binder and Broekel (2011), in a UK context, find being unemployed inhibits conversion of resources through capability into functioning while being self-employed stimulates such conversion in terms of enhancing personal confidence in social contexts. In the context of this paper, transnational corporations' HRD activities are viewed as important as potential conversion agents for people who are their employees in providing secure entitlements, enhancing capability development, and offering additional functionings.

The research questions addressed in this paper are:

- Can the capability approach enhance our understanding of the responses of transnational corporations to the challenges of operating in 'local' cultural contexts in the 'global south' when added to conventional human capital and human exploitation models of the world of work?

- Does our Ghanaian case study suggest similarities and differences in employees' experiences of such responses between transnational corporations with headquarters in North America, South Africa and Western Europe? 
- Could these differing responses be partly path dependent on the history of the local establishments comparing two new creations by transnational corporations with one establishment with a previous history in the public sector?

- What are the implications of the capability approach as applied in this paper for deepening global debates on decent work and corporate social responsibility?

\section{The capability approach and the world of work}

Sen's development of the capability approach in the 1980s required a move away from the moral horror of famine to more relativistic moral positions on social justice and its relationship to inequality. This increased relativism demanded a greater concern with deliberative capability as the means to decide what people have collective 'good reason to value'. High quality deliberative processes can be seen as institutional arrangements that permit conversion of entitlements into capability sets that increase the freedom to choose more valued functionings in a specific socio-cultural context.

Another aspect of the engagement between the capability approach and relativism is a concern with people's normative perceptions of their capability and functionings status. In the 1980s, Sen had puzzled over indicative data that women and men in Bengal with apparently similar health profiles expressed gender influenced, differing evaluations of their well-being with women generally being more positive. This concern over 'adapted preferences' (judgements based on differing 'subjective' base-lines of what is considered satisfactory) echoes through to today.

For instance, Lessmann and Bonvin (2011) use the capability approach to combine both more directly observable and individual employee testimony elements in a single holistic perspective on what constitutes satisfactory employment. Also Pinker (2009) takes a thought provoking look at gendered behaviour and outcomes in the workplace that challenges the basis of conventional affirmative action thinking. Arguably, encouraging greater social deliberation and more ethnographic research, in the spirit of the full capability approach, could reduce the 'noise' from adapted preferences and improve understanding of the social psychology of people in work.

By 2000, the Capability Approach had developed a holistic conceptual framework across the whole range of human activities, which we attempt to summarise in Figure 1. This framework appears very demanding in terms of a check-list of potential capability outcomes for even the most ambitious HRD interventions in the most socially responsible corporation. However, this paper suggests that, as a checklist, the framework does allow identification of all areas of either real gains or actual damage to capability in any sector and occupation and can be used as an analytical and evaluative framework for any HRD intervention.

In support of this contention, it is relevant to cite the main findings of the Executive Summary of the report on quality of work produced by the European Foundation for the Improvement of Living and Working Conditions. Employee performance is found to improve with:

- Training

- Career advancement plans and employment security 
Figure 1: Scoping a capabilitie's development profile - the range of potential capabilities people need to live a whole life with good quality well-being and low vulnerability

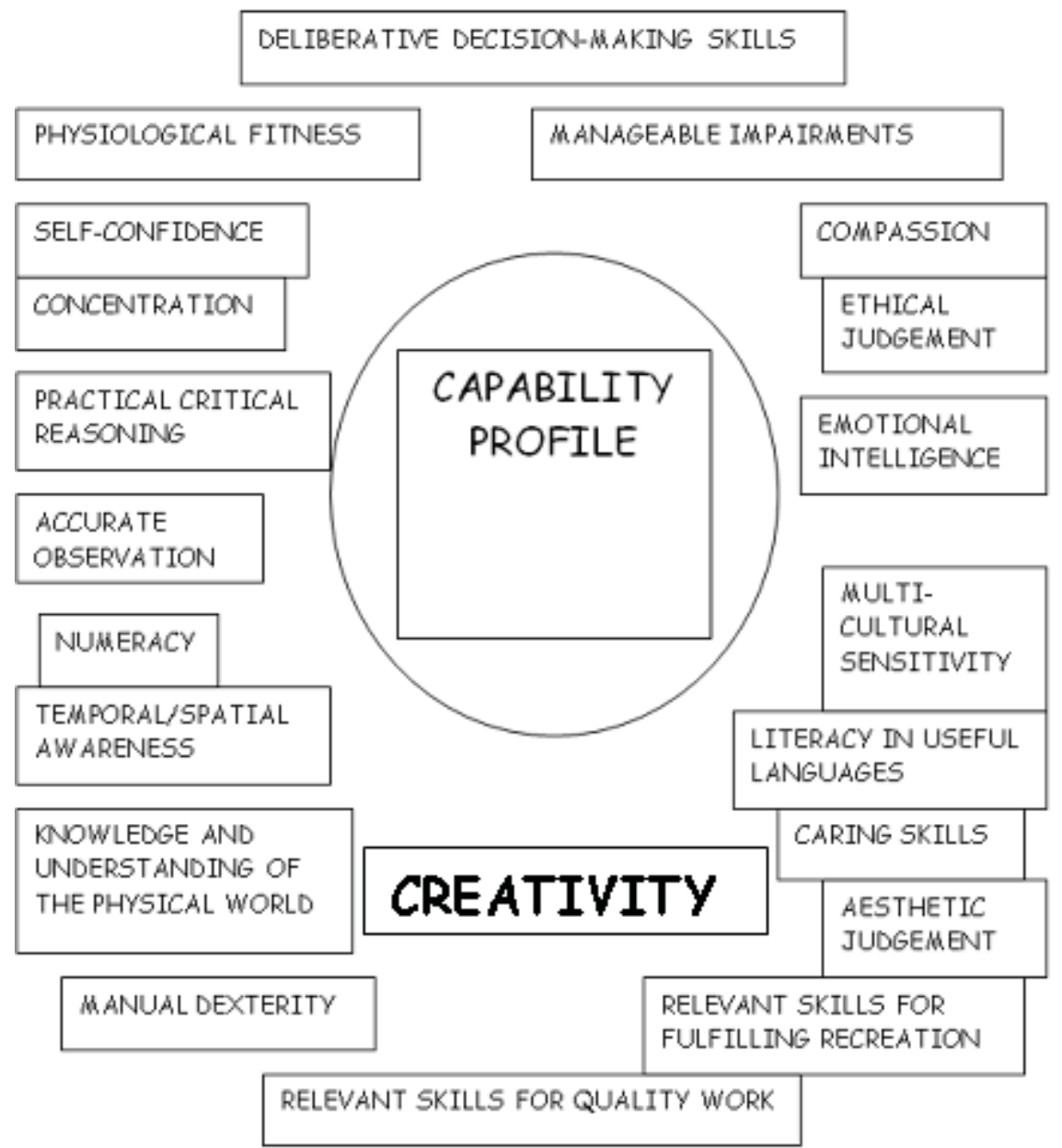

- Health, safety and well-being

- Work-life balance policies ${ }^{1}$

\section{Debates in the corporate HRD literature}

The global private sector has an important role to play in developing human resources as states have found their resources squeezed. The state can still provide the enabling policy, legal and institutional framework but directly improving capability is de facto increasingly becoming a question for private sector enterprises, through their human

1 http://www.eurofound.eu/publications/htmlfiles/ef1120.htm 
resources development policies and practices. However, in practice, the actual contribution of the private sector in the development of the human resources of a nation is debatable (ILO, 1996). UN organisations are especially concerned with the way transnational corporations, a powerful group within the private sector, might contribute to the human resources development of the indigenous people of the developing host countries in which they operate (ILO, 1981; UNCTAD, 1994; Enderwick, 1996; ILO, 2002).

In the growing literature on human resource development, there are claims that TNCs can contribute to broadly conceived international development. According to the International Chamber of Commerce's (ICC) Secretary General Maria Livanos Cattaui:

"The inescapable conclusion is that foreign direct investment coupled with the grassroots development of a viable private sector, are key to economic and social progress in Africa" (ICC, 2000).

The ILO report on employment and structural adjustment (ILO, 1992) reported that African governments had expressed the belief that:

"On the whole the activities of multinational enterprises had increased or tended to increase employment opportunities and improve standards in their country. In addition, the generation of direct and indirect employment, the introduction of new technology and management practices, the provision of training, the upgrading of skill requirements, increases in productivity and competitiveness among local firms were mentioned as important benefits" (ILO, 1992, p. 21).

There is a growing body of research into human resources development (HRD) often prescriptively and instrumentally associated with a burgeoning MBA sector in tertiary education. Central to the many definitions of human resources development that exists in the HRD literature (for example, Watkins, 1989; McLagan, 1983; McGoldrick, Stewart, \& Watson, 2002) is both skill formation and attitude change. Human resources development from a conventional perspective, at company level, is essentially concerned with improving the work-related skills of people for a specific organisation, but with individuals also seeing gains for themselves. In terms of the purpose of $\mathrm{HRD}$, there are certain distinctive strands from the literature that offer potential explanations of the possible HRD positions that can be adopted by organisations (including TNCs). They can be summarised as follows:

- The purpose of HRD within organisations is increased productivity/profitability (Lado \& Wilson, 1994; Huselid, 1995; Rummler \& Brache, 1995).

- The purpose of HRD within organisations is the development of self (Maslow, 1970; Aktouf, 1992; Barrie \& Pace, 1998).

- The purpose of HRD within organisations is skills developed in accordance with the psychological contract between employer and employee (either traditional job security or employability). Perceived violation by the employer of the psychological contract can have a negative impact on the employee and can be seen as a tension in the field of values (Baruch \& Hind, 1999; Dench, 1997; Robinson \& Rousseau, 1994). 
- The purpose of HRD is to enable the employee to act as a researcher and develop expertise through contextual learning and experimentation (Kohlberg \& Mayer, 1972; Kincheloe, 1995; Bereiter \& Scardamalia, 1993).

- The purpose of HRD is to set the necessary conditions for the organisation to develop an effective learning capability. (Shaw \& Perkins, 1991; West, 1994).

- The purpose of HRD is to pursue training and development in keeping with the career systems approach that has been adopted by the organisation (Sonnenfeld \& Peiperl 1988).

Only the first purpose lacks any sense of the concerns of the capability approach, including an important long term view of human improvement. Most of these HRD objectives look at HRD mainly from the perspective of the employer or the organisation and in terms of how HRD can help the organisation achieve its goals. As such, these aims only provide insights into part of the experience of the individual employees receiving HRD within organisations and do not provide insights into the potential impact of the HRD on employees' wider lives.

Part of this literature is explicitly concerned with international human resource management (IHRM) targeted at managers of TNCs operating across cultures. This has encouraged an element of cultural sensitivity about the language of human resource development which has strong links to the capability approach:

"the concept of HRM itself, like all social constructs, takes its character and quality, if not its very existence, from the socio-cultural and political economic context which gave birth to it" (Tayeb, 2005, p. 204).

Despite expressing some confidence in a universal best practice, Tayeb admits:

"MNCs may not always be able to devise and implement company-wide global HRM strategies and policies .... Notions such as 'modifications', 'adaptations and 'local variations' rather than 'global', 'international' and 'universal' more accurately characterize HRM in multinational companies” (Tayeb, 2005, p. 209).

Ozbilgin also adds

"Multinational companies, which set up branches in emerging or less-developed economies, predominantly originate from developed countries. This bodes difficulties in direct transfer of human resource practices, which are developed in advanced economies, to be implemented in countries with developing or less-developed economies, and has further implications for voice and representation of employees in host countries (Ozbilgin, 2005, p. 163).

Ozbilgin then goes on to distinguish exportive, adaptive, integrative, synergistic styles as options where only the last is transcendent (Ozbilgin, 2005, p. 163).

The Burke and Cooper (2005) collection of articles can be seen as representing the optimistic universalistic approach to HRM that "endorses ... balance: healthy people and healthy organizations" (ibid: 5). But, like much of this literature there is no recognition of the wider discourse in development studies on the concept of capabilities and none to exploitation in any of its forms (e.g. no mention of child labour).

Price (1997) has a relatively sensitive chapter on "culture" and HRM, though intimately linked to the challenge of ensuring "commitment" to the organisation (Price, 1997, p. 122-155). The approach appears less optimistic about developing a universal 
understanding than some mainstream literature, though optimistic about convergence towards a global managerial cultural community of interest displacing multiple local community cultures of place.

Sparrow et al (2004) argue from a more sceptical instrumental position that "in practice, global HRM seems to revolve around the ability of an organization to find a concept that has "relevance" to managers across several countries - despite the fact that they have different values embedded in different national cultures and despite the reality that these global themes may end up being operationalized with some local adaptation" (Sparrow et al., 2004, p. 110).

In terms of the capability approach, it is important to take into account the potential impact of HRD interventions on employees outside of the confines of the firm where the HRD was received. How do HRD interventions affect the agency (or power) of the employees receiving it and what potential impact can this HRD then have on the indigenous society outside of the organisation providing the HRD?

Strategic HRD within organisations, from the perspective of the capability approach, needs to looked at not just in terms of what is the purpose of HRD for the organisation, but also the impact of the HRD provided by the organisation on indigenous employees' values and what is the potential impact of the HRD received by the individual indigenous employees outside of the firm in the wider economy and society. Such concerns lend themselves analytically to exploration through the lenses of neoinstitutionalism and social regulation theory (Coster \& Leonard, 2011).

\section{Linking corporate HRD concerns to the capability approach}

Human Resource Development thinking tends to start from asking why people underperform in a workplace. In HRD language, relevant factors producing employee underperformance may include some or all of the following:

- Poor recruitment - under-qualified or over-qualified for tasks given?

- Personal negative characteristics, e.g. laziness, indiscipline

- Monetarily under-rewarded

- Poor physical environment, health and safety risks

- Bullying managerial style, lack of consultation/deliberative processes

- Boredom - no opportunities for expression of imagination/creativity

- Perception of absence of long term developmental/career opportunities

- Limited or negative social 'peer' relationships in work and lack of positive 'spread' effects to wider life

- Feeling undervalued personally and/or group cultural alienation

This paper is concerned with demonstrating how the capability approach can help integrate the last five factors in the list into a holistic, humanist framework for work being part of a whole well-lived life. In Aristotle's language, which inspires Martha Nussbaum as a capability theorist, this pattern of a whole well-lived life can be envisaged as eudaimonia (Nussbaum, 2006). 
To move towards an HRD image of improvement and a more positive language, the paper offers differing perceptions of employer-employee relationships, initially dichotomised into a set of conflictual perceptions paired with more synergistic relationships (Table 1).

Table 1: Universalist models of employer-employee relationships

\begin{tabular}{l|l}
\hline More negative perceptions & More positive perceptions \\
\hline - Conflictual absolute income seeking & - Mutual additional income seeking \\
- Bored alienation & - Creative expression \\
- Socially negative relationships & - Socially positive relationships \\
- Hierarchical quantitative performance measurement & - 360 degree qualitative developmental assessment \\
\hline
\end{tabular}

Over-arching these pairings is the space for genuine deliberation over the values that people have good reason to hold. Table 1 illustrates the realities in which employeremployee relationships are created as complex mixes of characteristics (most jobs contain some times, spaces and activities in which either more conflictual or more synergetic elements dominate). The role of 'progressive' Human Resource Development can be seen as seeking to change the mix towards more positive characteristics, though usually within cost and authority constraints set by employers and rights to change employment for employees.

In the language of the capability approach, HRD can be seen as attempting to fully use employees' current capabilities in carrying out a functioning at work. It may also involve as stimulating further capability development with a resulting improvement in functioning at work. In both roles, HRD may have positive spread/spillover effects into wider areas of life and hence improved overall well-being. In this respect, Lopes et al. (2011) find that the results of the European Working Conditions Survey show a link between perceptions of greater autonomy at work and greater participation in voluntary and political activities.

From this wider perspective, corporate HRD interventions can be analysed and evaluated as to how far they connect to the international Human Development agenda and the general improvement of human well-being in which the economic dimension is important but not exclusive. This agenda also has roots in Amartya Sen's Capability Approach and has been widely used to understand local level changes in well-being, though often neglecting the quality of employment experiences.

Thus, for the capability approach, it is important to take into account the potential impact of HRD on people, not only as employees, but in their lives both inside and outside the confines of the corporation and the specific, current tasks of the employees. The capability approach asks how HRD interventions change the well-being of the employees receiving them. The impact can be seen at four levels: e.g.

- improving valued specific skills and competence in their current jobs

- providing a more general capability to gain promotion in the corporation

- helping employability in other organisations or take up sustainable selfemployment 
- becoming a more effective agent in wider civil society or political processes Moving through the levels from top to bottom widens the impact of a HRD intervention from the immediate material interest of the employer to the wider capability development of the person employed.

\section{A general framework for comparing human exploitation and human capability approaches to HRD}

To highlight the specific contributions of capability approach, it is useful to compare it with older, well established theories of HRD impact. This paper compares three theories, namely human capital (Becker, 1975), human exploitation (Braverman, 1998) and human capability development (Sen, 1999).

Human capital focuses on increased productivity and profitability calculated in monetary terms; human exploitation theory's focus is unequal power and its reproduction, while human capability development theory's focus is human freedom and the expansion of choice over beings and doings that individuals have good reason to value in their socio-cultural context.

- Human capital theory suggests that there are potential outcomes of greater economic success for indigenous employees resulting from HRD provided by their TNC employer. This economic success may be instrumental as a means to raising employees' well-being.

- Human exploitation theory suggests that only negative disempowering outcomes can be expected by most employees as a result of so-called human resources "development" by their TNC employer. Such experiences may have 'backwash' effects in reducing a sense of agency as a citizen in wider life.

- Human capability development theory encourages more direct wide-ranging exploration of a societal dimension to HRD impact on indigenous employees of a TNC. More normatively, human capability development theory suggests that the benefits for indigenous employees of receiving human resources development at a TNC should be judged on whether this changing entitlement and increased capability contributes positively to the freedoms of indigenous employees in terms of increasing their ability to achieve higher well-being in terms of functionings they have good reason to value .

Within human capital theory, Becker (1975) differentiates between specific and general on the job training. Using his definitions of specific and general training, specific training in the TNC would be training that increased productivity of the individual trained more in the firm providing the training than potentially in other firms. In its most basic form, it would consist of specific instructions given to workers on the job. General training would be training conducted by the TNC that is useful to many firms in addition to the TNC providing it. Becker also added that, although much on-thejob training is neither completely specific nor completely general, on-the-job training, overall, did increase productivity more in the firm providing it and thus fell to some extent within the definition of specific training (Becker, 1975, p. 19, pp. 26-27).

Human capital theory, combining employer and employee outcomes, stresses that successful education and training lead to greater productivity of the employee, which re- 
sults in both greater income for the individual employee and greater profitability for the employer. In order to minimise 'free-rider' poaching by other firms, training within firms will tend to be firm specific (Becker, 1975; Allsopp, 1995). If human capital theory is representative of the reality of the experiences of the indigenous employees in a TNC, then the interviewed employees would recognise HRD interventions as positive in terms of economic gains from their work for the TNC.

Human capital theory can extend its reach to wider gains from HRD in terms of employees being able to move to higher productivity jobs in other firms or in selfemployment. Individual employees leaving the TNC, with the knowledge, skills and attitudes they have gained whilst working at the TNC, may have more choice of employment options. HRD activities giving rise to outcomes of economic success for the individual may also be shared, for example, with employees of their new employer or, if they have set up their own business, with their own employees. The development impact of this is that the employees of the new employer or the individual's own employees also gain improved knowledge, skills and attitudes that lead to real outcomes of economic success (and associated increases in income) for them as well. Thus in human capital theory, there can be spread effects (or spillovers) of HRD activities in terms of real material gains.

For human exploitation theory, Braverman (1998) saw training and development in the capitalist workplace as being about giving workers the minimum skills to be able to carry out the tasks in their job and to sustain or increase profitability.

"Training a worker means merely enabling him to carry out the directions of his work schedule. Once he can do this, his training is over" (Braverman, 1998, p. 309).

Braverman argued that managers control knowledge and that for managers, the instruction of workers in the simple requirements of capital is the aim of the upgrading of skills in workers (Braverman, 1998, p. 307, p. 309).

"The worker may remain a creature without knowledge or capacity, a mere hand by which capital does its work, but so long as he or she is adequate to the needs of capital the worker is no longer to be considered or called unskilled" (Braverman, 1998, p. 309).

Under human exploitation, the assumed experience of indigenous TNC employees below the elite managers in the TNC operation is that they get minimum or no training within the TNC operation. The concept of elitism as a philosophy of training, as explained by Reid, Barrington and Kenney (1992), is when a lot of training is seen as necessary and reserved for the elite, such as managers over a certain grade, but unnecessary for the rest of the employees in the organisation. This:

"has its roots in long established patterns of [training] provision which are seen to have served [an] ..organisation well over a substantial period of time" (Reid, Barrington et al., 1992:, p. 53).

Braverman's dichotomous model was derived from applying Marxian theory to USA assembly line manufacturing industry, though The Centre for Research on Multinational Companies documents cases of its continuing applicability in Asia. Adaptations are needed for other sectors where ethnographic research can uncover tensions on the frontiers between elite and non-elite workers (Thompson \& Cushen, 2011). 
Therefore, human exploitation theory at the workplace and individual level argues that non-elite employees are required by capitalist firms (through representative managers) to carry out instructions in a highly sub-divided division of labour and achieve the profitability goals of the capitalist firm. Any HRD activity for non-elite employees will be instrumental for the needs of capital. Non-elite employees are powerless with regard to their control of their working lives and have highly restricted other employment choices as a result of working for and receiving HRD from the capitalist firm (Braverman, 1998).

If human exploitation theory is representative of the reality of the experiences of the indigenous employees in a TNC, then the interviewees will express dissatisfaction with the amount, form and outcomes of HRD they receive. Outcomes of disempowerment are that indigenous employees below the elite managers in the TNC operation will claim they only get instructions related to specific tasks within the TNCs' operations, have limited skills development, and no room for creativity. Additionally, the non-elite employees will have a sense of having little or no choice with regard to employment options outside the TNCs and express a sense of alienation between work and their lives in wider Ghanaian society.

Human capability development stresses that HRD activities can be evaluated in terms of how far they contribute to the substantive freedoms of people to choose lifestyles they have good reason to value. The things of value to people are greatly influenced by the norms and mores of their society (Sen, 1999). The approach also highlights that individuals should gain more from HRD than greater productivity and income. Increased productivity is only one dimension of the substantive freedoms that people may seek. Development at the national level should be about the total impact of HRD in terms of increasing people's capability and providing opportunities to deliberate and exercise reasoned agency (Sen, 1987, 1990, 1999).

If human development theory is representative of the reality of the experiences of the interviewed indigenous employees in a TNC, then they will perceive positive spread effects linking the TNC's HRD activities and their wider lives. Following Sen's argument that the way people behave depends on their understanding of prevailing societal norms (Sen, 1999), it is analytically conceivable that there will be potential influence on the employing TNC's norms of the values of the indigenous people of the local society (within which the TNC is operating) as a result of these values flowing into the TNC from the surrounding society, through the indigenous employees. This has the potential to affect the work norms that exist within the TNC.

Vice versa, the work norms of the TNC can change the norms and practices of their indigenous employees. Therefore, there is also the potential for the outflow of norms from the TNC into the local society through the indigenous employees. This has the evaluative potential to be either beneficial to the local society and/or the TNC or negative to the local society and/or the TNC. The outcomes for indigenous employees of working for a TNC and receiving HRD from the TNC need to be judged on whether they perceive the HRD as contributing positively to the substantive freedoms that these employees have to achieve the things they have reason to value. 
The three analytical frameworks open up a range of possible well-being outcomes linked to wider development studies exploring positive or negative effects on human well-being beyond the conventional HRD managerialist discourse, while embracing insights from that discourse in the International Human Resource Management literature and its tendency to emphasise the human capital model, whether explicitly or implicitly. To summarise:

If there were human capital outcomes, it would be expected that there will be perceptions of some transferability of the knowledge and skills gained in terms of transferability of knowledge and skills outside of the TNC.

- In terms of the transferability of the knowledge and skills gained from training and development by the indigenous employees, if there were human exploitation outcomes, it would be expected that little knowledge and few skills would be perceived by the indigenous employees and none would be transferable outside of the TNC.

- If there were human capability positive developmental outcomes, it would be expected that knowledge and skill gains would be perceived as considerable and transferable not only in terms of work, but also contributing to the substantive freedoms of the indigenous employees (Sen, 1997, 2000).

Figure 2 illustrates the relationship between the three approaches.

Figure 2: From entitlements to capabilities to functionings, through human capital, human exploitation and human capabilies

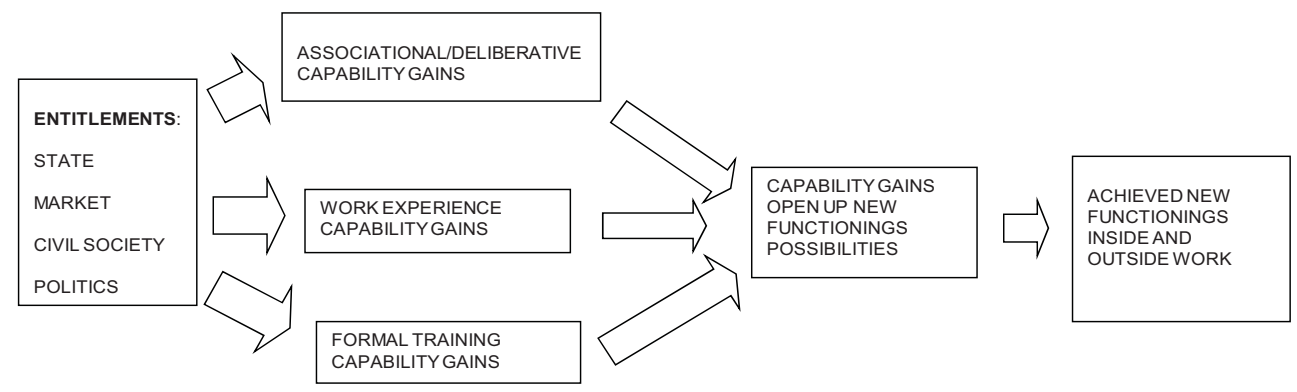

\begin{tabular}{|l|}
\hline RESTRICTED \\
ENTITLEMENTS: \\
INSECURITYI \\
VULNERABILITY TO \\
EXPLOITATION \\
ADVERSE \\
INCORPORATION/ \\
EXCLUSION \\
\hline
\end{tabular}
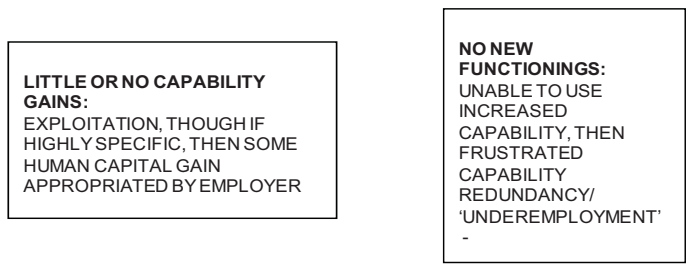

\section{An indicative case study}

To give an indicative empirical basis for this comparison we draw on fieldwork conducted in Ghana for one of the author's doctoral thesis (Eyeson, 2003) which was supervised by the other author. The research explored HRD in the Accra branches of three transnational corporations producing a similar product using similar technologies. 
Semi-structured interviews were conducted with a cross-section of the current permanent workforce (divided into 'managers' and 'workers' for the purposes of this paper) that is people most likely to receive more HRD from the TNCs compared to the growing numbers of casual/flexible workers liminally employed 'in' most formal organisations. Previous employees were also interviewed as a triangulation check against possible bias among existing employees that their employer might be informed of their negative assessments of HRD activities. The data collection process was aimed at capturing:

- Perceptions of the outcomes (intended and unintended) in the Ghanaian world of work that indigenous TNC employees claim to get from the human resources development they receive from their TNC employer.

- Perceptions of wider developmental impacts outside their employing TNC by indigenous TNC employees on how the TNC's HRD effort contributed (or not) to the general well-being of Ghanaian society.

Table 2 summarises the broad findings for the three TNCs (identified as "X", "Y" and "Z"). The HRD experiences of managers at X and Z, as well as workers in X, Y and $Z$, appear to have a human capital element in which material gains are valued. The experiences of workers and managers at $\mathrm{X}$ and $\mathrm{Z}$ as well as workers at $\mathrm{Y}$ were also in keeping with the human capital hypothesis which predicted that firms would provide widespread training but expect employees to bear some of the cost of general training because it raises the potential employability of the employee outside the firm and firms will provide employees mainly with specific training.

Table 2: Main outcomes for employees and ex-employees as a result of TNC training and HRD

\begin{tabular}{l|l|l|l}
\hline & $\begin{array}{l}\text { Human Capital outcomes (pri- } \\
\text { marily company specific skills } \\
\text { with limited transferability) }\end{array}$ & $\begin{array}{l}\text { Human exploitation outcomes } \\
\text { (strong sense of grievance/ } \\
\text { alienation) }\end{array}$ & $\begin{array}{l}\text { Human capabilities } \\
\text { 185esponse185nttal outcomes } \\
\text { (sense of deliberative engage- } \\
\text { ment) }\end{array}$ \\
\hline TNC X & $\begin{array}{l}\text { Managers } \\
\text { Workers }\end{array}$ & $\begin{array}{l}\text { Managers } \\
\text { Workers }\end{array}$ & \\
\hline TNC Y & $\begin{array}{l}\text { Managers } \\
\text { Workers }\end{array}$ & Workers & Managers \\
\hline TNC Z & $\begin{array}{l}\text { Managers } \\
\text { Workers }\end{array}$ & $\begin{array}{l}\text { Managers } \\
\text { Workers }\end{array}$ & \\
\hline
\end{tabular}

Source: Adapted from Eyeson (2003)

TNC X, headquartered in North America, was not perceived as encouraging and supporting the further education and professional development of the indigenous managers (including supervisors) that they desired and which would have made them more attractive to other employers or enhanced their self-employment opportunities. Workers in TNCs $\mathrm{X}$ and $\mathrm{Y}$ also claimed they were not offered HRD leading to their 185 esponssional development or to further their education. At TNC Z, however, there was some evidence that HRD might contribute to further education which might in turn increase wider employability. HRD management in TNC Z, headquartered in Western Europe, stated that it offered limited support for the further educa- 
tion of employees, although the $Z$ interviewees largely did not perceive the company as being supportive of their desires for further education. But TNC Z did provide IT training to managers, supervisors and workers, and this training was fully funded by the TNC.

Some managers in TNC Y, headquartered in South Africa, claimed they had received general training in knowledge that they did not have previously to which they did not contribute financially. They did see this HRD as increasing the potential for increased earnings as their improved knowledge made them more marketable, plus if they left the TNC, they potentially had more knowledge to share with their employees (if self employed) or with their colleagues (if employed). In terms of the spread of knowledge into the world of work outside of the TNC through the indigenous TNC employees, this can be seen as positive for Ghanaian economic development, though the turnover of employees is very low and therefore spread effects are weak.

The interview results also suggest elements of human exploitation. In all three TNCs, formal in-house training was primarily aimed at managers, not workers. This is consistent with the human exploitation hypothesis of minimal HRD for workers, with additions to skill and knowledge being concentrated at elite levels within the firms. Workers in $\mathrm{X}$ and $\mathrm{Y}$ claimed training was carried out in a rote, didactic fashion with no space for deliberative interaction.

Formal training provided by the TNC to managers in $\mathrm{X}$ and $\mathrm{Z}$ was claimed to be primarily aimed at instructing these managers how to do things the TNCs' way and thus consistent with a human exploitation approach in which indigenous managers were not part of the TNC ultimate 'elite'. Thus the findings point to the TNCs bringing into Ghana only that HRD relevant for their national operations. Therefore, the control and command of this knowledge did not lie with Ghanaian managers and engineers, as they were reliant on production processes and technical expertise embodied in machinery imported from the West. Thus, Ghanaian managers in the TNCs, although they instruct workers in the Ghanaian operation, are also themselves instructed by managers at the headquarters of the TNCs using amongst other things formal training and development, but not really transferring skills that could be used for autonomous creativity.

From the perspective of human capability development, TNC Y managers were able to obtain further education paid for by the company which had the potential to have a positive impact on their human development. Good quality further education should contribute to their ability to make more reasoned choices and thus assist in improving their substantive freedom to lead the lives they have reason to value. Thus, for the Y managers, there may be an element of human capability development. Also only in TNC Y was there any sensitivity to the wider cultural and societal context in which the TNC was operating, but this was a complex recognition that involved tolerance of non-deliberative, arbitrary authority and nepotism, alongside more positive socio-cultural values.

Thus all three frameworks showed some relevance in the analysis of findings from the three TNCs. Though the analytical territory for interpreting the data collected was primarily contested between human capital and human exploitation, the 
human capabilities development perspective had value both in widening the scope of the analysis of some actual practices and identifying deficits in other practices with strong human exploitation and more specific human capital elements.

The main difference that did exist, concerned the ad hoc approach to HRD in Y, that did not exist in $\mathrm{X}$ and $\mathrm{Z}$, and which had enabled the discretionary provision of further education and professional development to $\mathrm{Y}$ managers. There is an element of paradox in that TNC Y had the least developed formal HRD strategy. TNC Y's ad hoc approach to managerial HRD, along with the discretion enjoyed by heads of departments over training and development reflects to some extent the history of the establishment in the public sector. This could change with the introduction of a more formal training strategy and the increasing closer involvement of the TNC headquarters in HRD. HQ company documents suggested TNC Y in its home country has a more profit focussed and specific approach to its training and HRD of its employees. At the time of the research, TNC Y had been managing company Y for only three years and so it could be that at the time of the research, arguably TNC Y had not been operating in Accra long enough to effect strategic change in HRD strategy, compared with the public sector predecessor that previously ran the establishment.

In terms of the potential contribution to the development of Ghana's total human capability, the evidence of this research into TNCs in one manufacturing sector in Ghana points to very restricted human capability development being provided by the researched TNCs to their indigenous employees with few spread effects and some possible backwash effects. In terms of wider human capability development, any improved substantive freedom as a result of working for the TNC was unintended by the TNC e.g. those ex-employees who left their former TNC employer with a redundancy payment and then went on to pursue further education at their own expense.

There is some evidence of TNC practices having a negative impact on activities valued by indigenous employees e.g. having the time to attend important family occasions. Also the TNC practices generally fail to meet the longer term aspirations of employees for their own career development and the next generation. In terms of the human exploitation prescription for progressive change through class struggle, there is no evidence of indigenous workers demanding and gaining greater power over the use of their labour in the three TNCs.

The individual indigenous TNC employees themselves do report material benefits. They are in employment in a country with very limited formal employment opportunities. Being employed by a TNC is perceived as a success in itself. However, their broader development (i.e. their further education and professional development) is generally not being supported by the TNCs in a country where affordability of education is an issue. This means that the TNC may be denying these indigenous employees an opportunity to develop their capabilities as recommended in UN and ILO conventions, as without their employer's financial support, many of these indigenous employees will not be able to afford to pay for further education themselves.

The above conclusions suggest that these three TNCs are not being effective in promoting development of Ghana's human capability. These findings in Ghana could well be comparable to other African countries with similar economic conditions to 
Ghana, but with their own distinctive value systems and with other TNCs operating branches in low income economies employing indigenous employees. This paper is, however, not making claims to empirical generalisation, but using the fieldwork as a case study to demonstrate how the human capability approach can usefully supplement the better known human capital and human exploitation approaches to analysing HRD activities.

\section{Looking towards the global HRD discourse}

There are numerous current efforts to persuade TNCs to become more conscious developmental agents, though the effectiveness of these efforts is in question (UNRISD, 2010, p. 21). The Global Compact is the most direct effort to engage the private sector as a full partner in the international development agenda. Other initiatives are more sectoral looking towards fairer trade and redistributing shares of value added across commodity chains towards lower income participants. HRD concerns also find direct expression in two other initiatives coming from the UN system - 'decent work' and corporate social sesponsibility. Associated UN recommendations and conventions encourage larger employers including TNCs to support the professional development and further education of their indigenous employees, to help improve governance, and respect indigenous cultural values.

The ILO, under the banner of "decent work", has since 1999 been working towards securing decent and productive work for men and women everywhere in conditions of freedom, equity, security and human dignity (ILO, 1999; Somavia, 2000). The ILO Director General, Juan Somavia, said during a presentation on the ILO concept of "decent work" that it represented for people:

"work on which to meet the needs of their families in safety and health, educate their children, and offer them income security after retirement, work in which they are treated decently and their basic rights are respected" (Somavia, 2000, p. 17).

He added that:

"People across the world are vitally concerned with the preservation or promotion of values or goals which don't have price in the global market: environment, culture, security, freedom, knowledge, identity" (Somavia, 2000, p. 18).

As part of this decent work agenda, the ILO puts forward the proposition that there is an increasing recognition of the pivotal role of education and training for achieving both economic and social goals. No society can succeed in a globalized environment unless its people have adequate knowledge and skills. These are vital, not just for maintaining competitiveness and ensuring adaptable and productive enterprises, but also for achieving citizenship, personal and social capability development (ILO, 1999; Somavia, 2000).

Under the umbrella of the UN Global Compact initiative (UN 2002) (which encourages corporate social responsibility) and the ILO Tripartite Declaration of Principles concerning Multinational Enterprises and Social Policy (ILO 2002), TNC decision-makers could be encouraged to abide by the recommendations advocated by the ILO in the Tripartite Declaration, namely: to provide employees in the host country with general capability development; to participate, along with national government and private sector enterprises, in local programmes to encourage wider capability de- 
velopment in the general population; and to offer more opportunities within the TNC worldwide to develop the capabilities of indigenous managers (ILO, 2002).

As a final conclusion, we suggest global and national policy as well as corporate HRD discourses can benefit from using the concepts of the capability approach. The capability approach can underpin such "decent work" and "corporate social 189esponsebility" global initiatives, giving them a firmer conceptual foundation and a more holistic evaluative and prescriptive framework.

\section{References}

Aktouf, O. (1992). Management and theories of organizations in the 1990s: Toward a critical radical humanism? Academy of Management Review, 17(3), 407-431.

Allsopp, V. (1995). Understanding Economics. London: Routledge.

Barrie, J., \& Pace, W. (1998). Learning for organisational effectiveness: philosophy of education and human resource development. Human Resources Development Quarterly, 9(1), 39-54.

Baruch, Y., \& Hind, P. (1999). Perpetual motion in organizations: Effective management and the impact of the new psychological contracts on "survivor syndrome". European Journal of Work and Organizational Psychology, 8(2), 295-306.

Becker, G. S. (1975). Human capital: A theoretical and empirical analysis with special reference to education. New York: National Bureau of Economic Research.

Bereiter, C., \& Scardamalia, M. (1993). Surprising ourselves: An inquiry into the nature and implications of expertise. Chicago: Open Court.

Braverman, H. (1998). Labor and monopoly capital: Degradation of work in the $20^{\text {th }}$ century. New York, Monthly Review Press.

Binder, M., \& Broekel, T. (2011). Applying a non-parametric efficiency analysis to measure conversion efficiency in Great Britain. Journal of Human Development and Capabilities, 12(2), 257-282

Burke, R.J., \& Cooper, C.L. (eds.) (2005). Reinventing HRM: Challenges and new directions. Routledge: London and New York

Coster, S., \& Leonard, E. (2011). Human resource management and employment integration. Paper presented at the SASE Annual Conference, Madrid.

Dench, S. (1997). Changing skill needs: What makes people employable? Industrial and Commercial Training, 29(6), 190-93.

Enderwick, P. (ed.) (1996). Transnational corporations and buman resources. London: Routledge.

Eyeson, A. (2003) Human Resources Development, transnational corporations and indigenous employees in a developing country: A case study of the beverage industry in Ghana. PhD Thesis, Norwich UK, University of East Anglia.

Huber, G., Harries, J., \& Grant, S. (2011). Contributions of ethnography to the study of public services management. Public Management Review, 13(2), 209-225

Huselid, M. A. (1995). The impact of Human Resource Management practices on turnover, productivity, and corporate financial performance. The Academy of Management Journal, 38(3), 635-672.

ICC (2000). Multinationals "cautiously upbeat" on investment in Africa. Downloaded from http://www.iccwbo.org/home/news

ILO (1981). Multinationals training practices and development. Geneva: International Labour Organisation.

ILO (1992). Follow-up on the bigh level Mmeeting on employment and structural adjustment, committee on employment, governing body. Geneva: International Labour Organisation.

ILO (1996). ILO enterprise forum: Summary of proceedings. Geneva: International Labour Office.

ILO (1999). Report of the director-general: Decent work. Downloaded from http://www.ilo.org/public/english/standards/relm/ilc/ilc87/rep-i.htm on 13th October 2002.

ILO (2000). Conclusions concerning human resources training and development. International Labour Conference Proceedings, 88th Session. Geneva: International Labour Office.

ILO (2002). A guide to the tripartite declaration of principles concerning multinational enterprises and social policy. Geneva: International Labour Office. 
Kincheloe, J. L. (1995). Toil and trouble: Good work, smart workers and the integration of academic and vocational education. New York: Peter Lang.

Kohlberg, L., \& Mayer, R. (1972). Development as the aim of education. Harvard Educational Review, 42(4), 449-496.

Lado, A. A., \& Wilson, M. C. (1994). Human resource systems and sustained competitive advantage: a competency-based perspective. Academy of Management Review, 19(4), 699-727.

Lessmann, O., \& Bonvin, J.-M. (2011). Job-satisfaction in the broader framework of the capability approach. Management Revue, 22(1), 84-99

Lopes, H., Calapez, T., \& Lagao, S. (2011). Autonomy at work: trends and challenges. Paper presented to the 2011 SASE Annual Conference, Madrid.

Maslow, A. H. (1970). Motivation and personality. New York: Harper and Row.

McGoldrick, J., Stewart, J., \& Watson, S. (2002). Researching HRD: Philosophy, process and practice. In J. McGoldrick, J. Stewart, \& S. Watson (eds.), Understanding Human Resource Development: A researchbased approach. London: Routledge.

McLagan, P. A. (1983). Models for excellence. Alexandria, VA: ASTD Press.

Nussbaum, M (2006). Education for democratic citizenship. Transcript of public lecture presented at ISS on 10 March 2006, Den Haag, ISS.

Ozbilgin, M (ed.) (2005). International Human Resource Management: Theory and practice. Palgrave Macmillan: Basingstoke and New York.

Pinker, S (2009) Sexual paradox. Totonto: Vintage Canada.

Price, A. (1997). Human Resource Management in a business context. Thomson Business Press: London and Boston.

Reid, M. A, Barrington, H., \& Kenney, J. (1992). Training interventions: Managing employee development. London: Institute of Personnel Management.

Robinson, S. L., \& Rousseau, D. M. (1994). Violating the psychological contract: not the exception but the norm. Journal of Organizational Behaviour, 15, 245-259.

Rummler, G. A., \& Brache, A. P. (1995). Improving performance: How to manage the white space on the organisation chart. San Francisco: Jossey-Bass.

Sen, A (1981) Poverty and famine: An essay in entitlement and deprivation. Oxford: Clarendon Press

Sen, A. (1987). The standard of living. Cambridge: Cambridge University Press.

Sen, A. (1990). Justice: Means versus freedom. Philosophy and Public Affairs, 19(2), 111-121.

Sen, A. (1997). Human capital and human capability. World Development, 25(12), 1959-1961.

Sen, A. (1999). Development as freedom. Oxford: Oxford University Press.

Sen, A. (2000). Work and rights. International Labour Review, 139(2), 119-128.

Shaw, R., \& Perkins, D. (1991). Teaching organisations to learn. Organization Development Journal, Winter, 112-26.

Somavia, J. (2000). Perspectives on decent work. Geneva: International Labour Organisation.

Sonnenfeld, J. A., \& Peiperl, M. A. (1988). Staffing policy as a strategic response: A typology of career systems. Academy of Management Review, 13(4), 588-600.

Sparrow, P, Brewster, C., \& Harris, H. (2004). Globalizing human resource management. Routledge: London and New York.

Tayeb, M. H. (2005). International Human Resource Management: A multinational company perspective. Oxford and New York: Oxford University Press.

Thompson, P., \& Cushen, J. (2011). Doing the "right thing": New buman resource management and the angry, highperforming knowledge worker. Paper presented at the SASE Annual Conference, Madrid.

UN (2002). Global compact. Downloaded from http://65.214.34.30/un/gc/unweb.nsf/ on 25/09/2002.

UNCTAD (1994). World investment report: TNCS, employment and the workplace. New York, UN.

UNRISD (2010). Overview: Combating poverty and inequality. Geneva: United Nations Research Institute for Social Development

Watkins, K. (1989). Business and industry. In S. Merriam \& P. Cunningham (eds.), Handbook of adult and continuing education. San Francisco: Jossey-Bass.

West, P. (1994). The concepts of the learning organisation. Journal of European Industrial Training, 18(1), $15-21$. 